\title{
Unusual cause of intussusception
}

\author{
Naveen Voore, ${ }^{1}$ Larry Weisner ${ }^{2}$
}

${ }^{1}$ Department of Internal Medicine, Riverside Shore Memorial Hospital, Nassawadox, Virginia, USA ${ }^{2}$ Department of General Surgery, Riverside Shore Memorial Hospital, Nassawadox, Virginia, USA

\section{Correspondence to}

Dr Naveen Voore

voorenaveen@yahoo.com

Accepted 7 August 2015

\section{DESCRIPTION}

An 87-year-old woman with a known history of coronary artery disease, hypertension and hyperlipidaemia, presented with gradually worsening abdominal pain and recurrent vomiting over a few days. On examination, she was hypotensive, tachycardic and in respiratory distress. She was emergently intubated, started on vasopressor agents and admitted to the intensive care unit.

CT scan of the abdomen showed gallstone ileus with secondary intussusception and obstruction of the proximal jejunum (figures 1-4). This prompted a surgical consult. Owing to rapid deterioration of the patient's condition, her family chose for her to

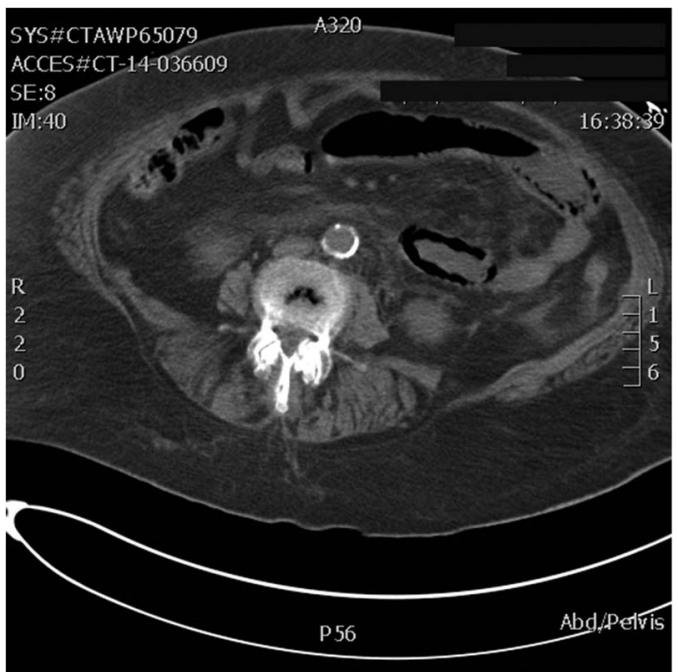

Figure 1 CT scan of the abdomen showing intussusception of the small bowel segment.

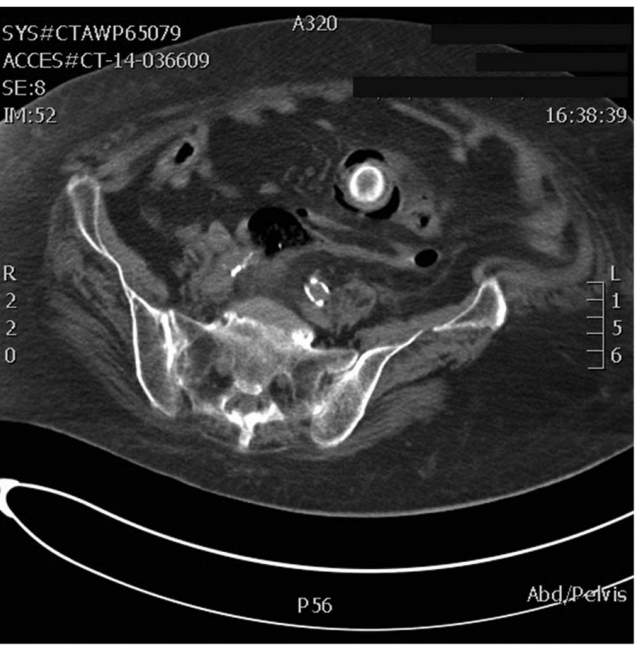

Figure 2 CT scan of the abdomen showing a $2 \mathrm{~cm}$ gallstone in the small bowel, causing intussusception. not undergo surgery and decided to opt for comfort measures. The patient passed away some hours later.

Intussusception is very rare in adults. ${ }^{1}$ It occurs due to a pathological lead point within the bowel, pulled by normal peristalsis and telescoped into another segment of bowel. Various causes of intussusception have been reported in the literature, however, our patient's case is the first to describe

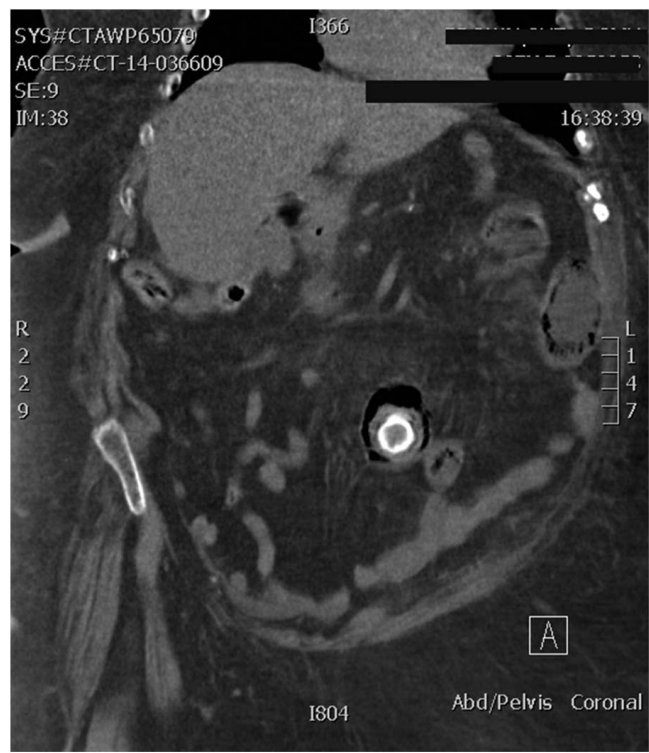

Figure 3 CT scan of the abdomen showing a gallstone in the small bowel and telescoping of bowel loops.

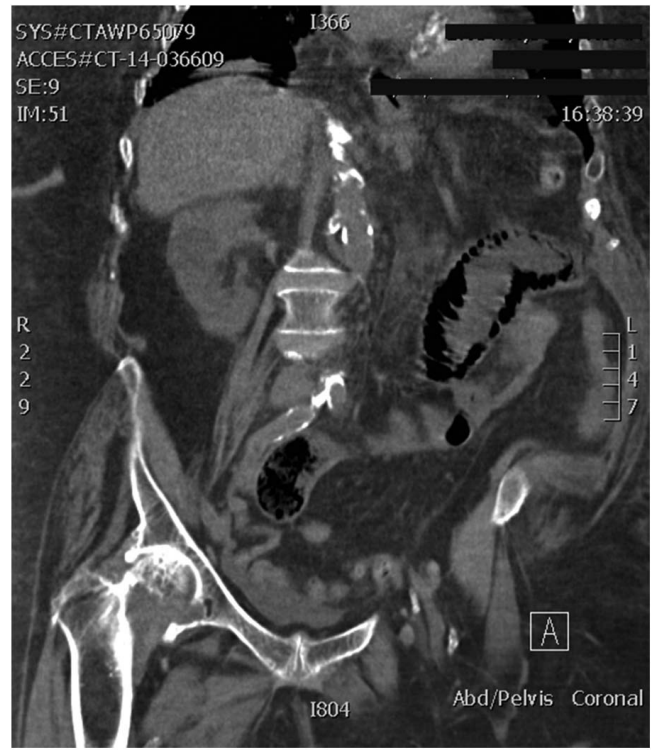

Figure 4 CT scan of the abdomen with coronal view showing intussusception of the small bowel. 
obstruction with intussusception due to a gallstone as the lead point in the jejunum.

The most common symptom at presentation is abdominal pain, however, nausea, vomiting, fever and bloody diarrhoea can also occur. CT is the most sensitive test for diagnosis and it can distinguish conditions with or without a lead point. ${ }^{2}$ A 'target sign' is the most characteristic finding on CT scan.

\section{Learning points}

- Adult intussusception is a rare condition requiring a high index of suspicion.

- Treatment depends on the cause, location of the bowel segments and age of the patient.
Management of intussusception depends on the cause, symptomology and the segment of the bowel involved, however, surgery is the mainstay of treatment in adult patients, especially if the small bowel is involved.

Contributors NV was involved in patient care during hospitalisation, as well as in writing, editing and submitting the manuscript to the journal. LW was the surgeon involved in patient care, and also helped in writing and editing the manuscript.

Competing interests None declared.

Patient consent Obtained.

Provenance and peer review Not commissioned; externally peer reviewed.

\section{REFERENCES}

1 Zubaidi A, Al-Saif F, Silverman R. Adult intussusception: a retrospective review. Dis Colon Rectum 2006:49:1546-51.

2 Marinis A, Yiallourou A, Samanides $L$, et al. Intussusception of the bowel in adults: a review. World J Gastroenterol 2009;15:407-11.

Copyright 2015 BMJ Publishing Group. All rights reserved. For permission to reuse any of this content visit http://group.bmj.com/group/rights-licensing/permissions.

BMJ Case Report Fellows may re-use this article for personal use and teaching without any further permission.

Become a Fellow of BMJ Case Reports today and you can:

- Submit as many cases as you like

- Enjoy fast sympathetic peer review and rapid publication of accepted articles

- Access all the published articles

- Re-use any of the published material for personal use and teaching without further permission

For information on Institutional Fellowships contact consortiasales@bmjgroup.com

Visit casereports.bmj.com for more articles like this and to become a Fellow 